\title{
The psychiatric patient in emergency room and Z zone
}

\author{
Assunta Lepri ${ }^{1 *}$, Nicola Gianmarco Ponsillo ${ }^{4}$, Vincenzo Spatuzzi ${ }^{3}$, Franca Veschi ${ }^{2}$ \\ From $1^{\text {st }}$ International Congress on Neurobiology and Clinical Psychopharmacology and European \\ Psychiatric Association Conference on Treatment Guidance \\ Thessaloniki, Greece. 19-22 November 2009
}

\section{Background}

Public mental health in a smal area of 8 boroughs and 74,753 inhabitans in the centre of Italy. Mental Health Departement during 1 year:almost 3500 psychiatric patients: $2.8 \%$ of the inhabitans of this small area. people presenting psychiatric desorders during the life, are estimated 25\%; and then in this area possibly will be 28,000 persons who needed psychiatric help (OMS: 2001 Mental Health report).

Bipolar desorders $33 \%$, anxiety and DAP 28\%, schizophreniza $12 \%$, borderline desorders $7 \%$, psychosomatic desorders compulsive behaviour $6 \%$, psychiatric symptoms in neurological desorders $5 \%$, bhavioural desorder $4 \%$, social problems $2.8 \%$, il $1.5 \%$ eating desorders, psychiatric symptoms abuse related $0.7 \%$.

\section{Materials and methods}

File archives research.

\section{Results}

Standardized initial approach step by step in the emergency room or $\mathrm{Z}$ zone.

\section{Conclusions}

The psychiatric patient in emergency room and $\mathrm{Z}$ zone.

Drug Treatment parenterally administered.

Conscious or unconscious patient.

Step 1 objective problems caused by the initial approach

Step 2 difficulties of gathering initial anamnesis information

${ }^{1}$ Mental Health Departement, North Umbria, Italy
Step 3 therapeutics start (usually not standardized attempts of limiting drugs or persuasion method) or treatment of an unconscious patient with suicidal mania

Step 4 finding a suitable hospitalization area in advance to deal with the patient.

\section{Author details}

${ }^{1}$ Mental Health Departement, North Umbria, Italy. ${ }^{2}$ Emergency Departement 118, North Umbria, Italy. ${ }^{3}$ Mental Health Departement ASL NA, Naples, Italy.

${ }^{4}$ Italian Association Psychiatrist AIPSIMED.

Published: 22 April 2010

doi:10.1186/1744-859X-9-S1-S171

Cite this article as: Lepri et al: The psychiatric patient in emergency room and Z zone. Annals of General Psychiatry 2010 9(Suppl 1):S171.
Submit your next manuscript to BioMed Central and take full advantage of:

- Convenient online submission

- Thorough peer review

- No space constraints or color figure charges

- Immediate publication on acceptance

- Inclusion in PubMed, CAS, Scopus and Google Scholar

- Research which is freely available for redistribution

Submit your manuscript at www.biomedcentral.com/submit 